\title{
DAMPAK PHYSICAL DISTANCING TERHADAP KEMAMPUAN SOSIAL PEMUDA
}

\author{
Mirnawati A. Mauludu \\ Institut Agama Islam Negeri Manado \\ E-mail: mirnawati@iain-manado.ac.id
}

\begin{abstract}
This research aims to study the impact of physical distancing on the youth's social abilities. This research using a qualitative approach by observation, interviews, and documentation to data collects. This study involved those who participated in youth organizations (PMRD) in Sindulang Satu Lingkungan I Village, Tuminting District, Manado City. The results show that the physical distancing on the youth's social abilities is that they do not get obstacles to communicating and educating the public regarding Covid-19 by utilizing social media. In terms of social interaction, there is still a lack of youth interest in participating in youth organizations (PRMD), whether there is physical distancing or not. Regarding youth socialization (PRMD), it has an active role in minimizing the spread of Covid-19 by distributing free masks to the public and collaborating with the Ansor Youth to spray disinfectant liquid in the Darussalam Sindulang I Mosque environment.
\end{abstract}

Keywords: Impact, Physical Distancing, Covid-19, Social Ability, Youth.

\begin{abstract}
ABSTRAK
Penelitian ini bertujuan untuk mengetahui dampak physical distancing terhadap kemampuan sosial pemuda. Penelitian ini menggunakan pendekatan kualitatif dengan melakukan observasi, wawancara dan dokumentasi. Penelitian ini melibatkan pemuda yang ikut serta dalam organisasi kepemudaan (PMRD) di Kelurahan Sindulang Satu Lingkungan I Kecamatan Tuminting Kota Manado. Hasil dari penelitian ini menunjukkan bahwa physical distancing tidak menghalangi kemampuan sosial pemuda di Kelurahan Sindulang Satu Lingkungan I Kecamatan Tuminting Kota Manado untuk berkomunikasi dan mengedukasi masyarakat terkait Covid-19 dengan memanfaatkan media sosial. Dalam hal interaksi sosial masih kurangnya minat pemuda untuk ikut serta dalam organisasi kepemudaan (PRMD) baik ada atau tidaknya pemberlakuan physical distancing. Terkait dengan sosialisasi pemuda (PRMD) sangat berperan aktif dalam meminimalisir penyebaran Covid-19 dengan membagikan masker gratis kepada masyarakat dan bekerjasama dengan Pemuda Ansor untuk penyemprotan cairan desinfektan di lingkungan Masjid Darussalam Sindulang I.
\end{abstract}

Kata Kunci: Dampak, Physical Distancing, Covid-19, Kemampuan Sosial, Pemuda.

\section{PENDAHULUAN}

Manusia adalah makhluk sosial yang tidak mampu hidup sendiri, mereka butuh interaksi dengan manusia lain dan interaksi sosial merupakan kebutuhan kodrati yang harus dimiliki oleh setiap manusia (Syaefullah, 2012). Dari interaksi tersebut manusia bisa hidup sebagai subjek dan objek karena jika manusia hidup hanya sebagai subjek maka manusia tidak mungkin dapat hidup bermasyarakat, sebaliknya apabila manusia hanya hidup sebagai objek maka hidupnya tidak lebih tinggi dari makhluk ciptaan Tuhan lainnya. Karena pada dasarnya manusia diciptakan sebagai makhluk yang paling sempurna 
diantara makhluk ciptaan Tuhan yang lainnya, sebagaimana firman allah dalam QS. At-Tiin ayat 4:

"Sesungguhnya kami telah menciptakan manusia dengan sebaik-baiknya..."

Manusia membutuhkan orang lain untuk bisa bertahan hidup, suatu pergaulan bisa terjadi apabila sudah ada Give and Take dari masing-masing anggota masyarakat tersebut. Jadi, sudah jelas bahwa hidup individu dan masyarakat tidak dapat dipisahkan dan selalu berinteraksi antara yang satu dengan lain (Ahmad, 2007). Dari Interaksi sosialnya, maka seorang manusia dapat memenuhi kebutuhan akan kasih sayang dan cinta, di sinilah peran orang tua, teman dan lingkungan yang mendukung menjadi faktor penentu kematangan sosial seseorang.

Pada akhir tahun 2019 dunia dikagetkan oleh wabah virus corona atau sering disebut Covid-19. Virus corona atau Severe Acute Respiratory Syndrome Coronavirus 2 (SARS-coV-2) adalah virus yang menyerang sistem pernapasan. Penyakit karena infeksi virus ini disebut Covid-19. Virus corona bisa menyebabkan gangguan ringan pada sistem pernapasan, infeksi paru-paru yang berat, hingga kematian (www.covid.go.id).
Severe Acute Respiratory Syndrome Coronavirus 2 (SARS-coV-2) yang lebih dikenal dengan nama virus corona adalah jenis baru dari virus corona yang menular ke manusia. Walaupun lebih banyak menyerang lansia, virus ini sebenarnya bisa menyerang siapa saja, mulai dari bayi, anak-anak, hingga orang dewasa, termasuk ibu hamil dan ibu menyusui (www.alodokter.com).

Infeksi virus corona disebut Covid19 (Corona Virus Disease 2019) dan pertama kali ditemukan di Kota Wuhan, China pada akhir Desember 2019. Virus ini menular dengan sangat cepat dan telah menyebar ke hampir semua Negara, termasuk Indonesia, hanya dalam waktu beberapa bulan.

Hal tersebut membuat beberapa negara menerapkan kebijakan untuk memberlakukan lockdown dalam rangka mencegah penyebaran virus Corona. Di Indonesia sendiri, diberlakukan kebijakan Pembatasan Sosial Bersakala Besar (PSBB) untuk menekan penyebaran virus ini. Juru bicara pemerintah ntuk penanganan Covid19 Achmad Yurianto mengatakan, kebijakan pembatasan sosial berskala besar (PSBB) merupakan upaya memperkuat penerapan pembatasan fisik atau Physical Distancing demi mencegah penyebaran virus corona. Kebijakan PSBB itu diatur dalam PP Nomor 21 Tahun 2020 tentang 
Pembatasan Sosial Berskala Besar dalam rangka percepatan Penanganan Covid-19 yang ditanda tangani oleh presiden Joko Widodo. Selanjutnya pelaksanaan PP itu diturunkan dalam Peraturan Manteri Kesehatan Nomor 9 Tahun 2020 tentang Pedoman PSBB (https://nasional.kompas.com).

World Health Organization (WHO) telah mulai menggunakan istilah physical distancing yang artinya jarak fisik sebagai cara untuk menghindari penyebaran virus corona lebih luas (www.covid.go.id). Langkah ini disebut sebagai "arah yang tepat" oleh para ahli. Penyebaran virus corona baru ini tergolong cepat dan telah menjangkit ratusan negara. Berbagai kebijakan pun dilakukan oleh setiap negara yang mengonfirmasi Covid-19 di negaranya, mulai dari penutupan bandara hingga pemberlakuan pembatasan terhadap pergerakan warganya. Beberapa contoh dari physical distancing ialah tidak melakukan aktivitas dengan berkerumun. Namun tidak sedikit masyarakat yang masih melakukan aktivitas di luar rumah dengan aktivitas biasa contohnya pada Kelurahan Sindulang Satu Lingkungan I Kecamatan Tuminting Kota Manado.

Mahfud MD sebagai Menteri Koordinator Bidang Hukum, Politik dan Keamanan mengatakan pemerintah mengubah istilah pembatasan sosial (social distancing) menjadi menjaga jarak fisik (physical distancing). Sebab, istilah social distancing dianggap kurang bagus oleh pemerintah. Mahfud mengatakan, langkah tersebut diambil hati-hati setelah melihat penanganan Covid-19 di sejumlah negara, ia mencontohkan Italia menggunakan konsep karantina wilayah (lockdown) dalam penanganan Covid-19. Akan tetapi, jumlah korban justru semakin besar karena perilaku masyarakat yang tidak mematuhi perintah lockdown hingga ratusan orang terinfeksi.

Kedua, Indonesia melihat cara Inggris menangani Covid-19 dengan cara care immunity. Pemerintah membiarkan masyarakat bertarung di komunitas sehinnga penyakit dianggap menghilang. Hal tersebut, kata Mahfud, "Itu juga sangat tidak manusiawi, itu orang disuruh cari selamat sendiri-sendiri”. Oleh karena itu pemerintah menerapkan physical distancing. Pemerintah ingin agar kontak dengan orang lain diminimalisir. Kemudian, jika ada pertemuan, masyarakat diminta menjaga jarak hingga satu meter serta rajin membersihkan diri dan jika memungkinkan selalu gunakan masker (https://tirto.id).

WHO menyarankan melakukan physical distancing sebagai frasa untuk mengeduksi masyarakat. Saran ini diberikan dengan dasar physical distancing 
memiliki makna jarak fisik bukan jarak sosial dengan orang-orang terdekat kita.

Dr. Drajat sendiri merespon baik dengan adanya saran dari WHO tersebut. Namun disituasi saat ini yang paling adalah memberikan sosialisasi dan edukasi kepada masyarakat untuk menjaga jarak satu dengan yang lain. Sehingga penularan virus ini bisa terputus.

Negara Indonesia dengan latar belakang budaya yang kuat membuat kebijakan physical distancing ini sedikit sulit untuk diberlakukan. Contohnya di Kelurahan Sindulang Satu Lingkungan I Kecamatan Tuminting Kota Manado, masyarakat masih beraktivitas seperti biasanya bahkan tanpa menggunakan alat pelindung kesehatan (masker). Tidak hanya itu beberapa aktivitas ibadah masih tetap dijalankan bersama-sama dengan memegang teguh kepercayaan bahwa Tuhan akan melindungi mereka. Padahal sudah dikeluarkan secara resmi oleh pihakpihak berwenang dan pihak ahli untuk beribadah dari rumah. Berbagai kebijakan yang sudah dikeluarkan pemerintah sudah dikaji sebelumnya sehingga peran-peran pemuda penting dan berpengaruh dalam menyampaikan kebijakan tersebut.

Gerakan serentak oleh semua lini perlu dilakukan untuk melakukan sosialisasi mulai dari tokoh-tokoh masyarakat, tokoh-tokoh agama, pendidikan, pejabat pemerintah, tak terkecuali bagi pemuda serta semua yang memiliki pengaruh besar di masyarakat. Karena ketika dari kelompok medis sudah berusaha untuk mengobati tetapi masyarakat tidak mendukung akan sama saja. Selain itu, masyarakat bisa bahu membahu untuk memenuhi kebutuhan di masyarakat. Bagi mereka yang memiliki kondisi perekonomian menengah ke atas bisa memberikan bantuan untuk kalangan menengah ke bawah. Sehingga kebijakan physical distancing dan Work From Home (WFH) bisa berjalan dengan baik dan maksimal. Karena masyarakat tidak menghawatirkan pendapatan mereka.

Melalui hal tersebut dia atas penulis kemudian tertarik untuk melakukan penelitian mengenai "Dampak Physical Distancing Terhadap kemampuan Sosial Pemuda".

\section{METODE PENELITIAN}

Penelitian ini difokuskan pada dampak physical distancing terhadap kemampuan sosial pemuda. Penelitian ini bermaksud meneliti tentang dampak physical distancing terhadap kemampuan sosial pemuda di Kelurahan Sindulang Satu Lingkungan I Kecamatan Tuminting Kota Manado, serta upaya pemuda dalam meminimalisir penyebaran Covid-19 lingkungan tersebut. Oleh karena itu, 
penggunaan pendekatan penelitian kualitatif adalah cocok digunakan dalam mengungkapkan fakta-fakta sebagai kebenaran empiris dalam penelitian ini (field research).

Penelitian ini dilakukan pada saat pelaksanaan kegiatan sosial oleh pemuda di Kelurahan Sindulang Satu Lingkungan I Kecamatan Tuminting Kota Manado. Subjek penelitian ini yaitu Pemuda yang bertempat tinggal di Kelurahan Sindulang Satu Lingkungan Satu Kecamatan Tuminting Kota Manado, khususnya pemuda yang tergabung dalam organisasi kepemudaan (PRMD). Untuk mendapatkan data yang diperlukan berkenaan dengan fokus penelitian, maka dilakukan observasi, wawancara dan dokumentasi. Selanjutnya, analisis data dilakukan melalui teknik reduksi data, penyajian data, dan simpulan.

\section{HASIL DAN PEMBAHASAN}

Berdasarkan penelitian yang penulis lakukan dapat disimpulkan bahwa Dampak physical distancing terhadap kemampuan sosial pemuda adalah sebagai berikut:

1. Kemampuan sosial (komunikasi):

Dari hasil tersebut penulis mengambil kesimpulan bahwa dampak dari physical distancing terhadap kemampuan sosial pemuda yang berada di Kelurahan Sindulang Satu Lingkungan I Kecamatan Tuminting, khususnya pemuda yag tergabung dalam (pemuda remaja Masjid Darussalam Sindulang I), tidak menghalangi mereka untuk berkomunikasi dan memberikan informasi/edukasi mengenai covid-19 kepada masyarakat dengan memanfaatkan media sosial, meskipun ditengah pandemi Covid-19 dan dalam pemberlakuan physical distancing.

2. Kemampuan sosial (interaksi sosial):

Berdasarkan hasil yang penulis dapatkan maka dapat disimpulkan bahwa dampak dari physical distancing terhadap kemampuan sosial pemuda di Kelurahan Sindulang Satu Lingkungan I Kecamatan Tuminting, dengan atau tidak adanya pemberlakuan physical distancing atau pandemi Covid-19, masih kurangnya minat hubungan sosial atau keikutsertaan pemuda dalam organisasi kepemudaan bisa dilihat dalam jumlah anggota (PRMD) yang berjumlah 20 pemuda.

3. Kamampuan sosial (sosialisasi):

Dari hasil tersebut penulis dapat mengambil kesimpulan bahwa dampak dari physical distancing terhadap kemampuan sosial dalam hal sosialisasi atau penyesuaian diri dengan lingkungannya, pemuda yang berada di Kelurahan Sindulang Satu Lingkungan I Kecamatan Tuminting Kota Manado adalah dengan mengikuti saran dari 
instansi kesehatan atau pemerintah dalam meminimalisir penyebaran Covid19 adalah dengan melakukan penyemprotan cairan desinfektan, khususnya di lingkungan Masjid Darussalam Sindulang I.

\section{PENUTUP}

Penelitian ini menunjukkan bahwa physical distancing tidak menghalangi pemuda yang tergabung dalam organisasi pemuda (PRMD) untuk berkomunikasi serta mengedukasi masyarakat terkait penyebaran Covid-19. Pemuda di wilayah Sindulang memanfaatkan sosial media sebagai media komunikasi dan berinteraksi serta memberikan informasi terkait Covid 19.

\section{DAFTAR PUSTAKA}

Ahmad, A. (2007). Psikologi Sosial. Jakarta: PT. Rineka Cipta.

Ahmad, A. (1998) Psikologi Sosial. Jakarta: Gramedia.
Dudung, A. (1995). Interaksi sosialkeagamaan PP. Wahid Hasyim dan Masyarakat Desa Condong Catur, Depok, Sleman, Jurnal Penelitian Agama, Vol. Januari-April.

Daradjat, Z. (1976). Ilmu Jiwa Agama. Jakarta: Bulan Bintang.

Effendy, O. U. (1989). Kamus Komunikasi. Bandung: Mandar Maju.

Nasrullah. (1995). Media sosial: Perspektif komunikasi, budaya dan sosioteknologi. Simbiosa Rekatama Media

Supratiknya, A. (1995). Komunikasi Antar Pribadi. Yogyakarta: Penerbit Kanisius.

Syaefullah, U. (2012) Psikologi Perkembangan dan Pendidikan. Bandung: Pustaka Setia.

Susanto, A. S. (1979). Pengantar Sosiologi dan Perubahan Sosial. Bandung: Bina Cipta.

Zainuddin, A. Rahma. (1993). Komunikasi Politik Indonesia:barat, Islam dan Pancasila, sebuah Pendekatan Teoritis, dalam Maswadi Rauf dan Mappa Nasrun (ed), Indonesia dan Komunikasi Politik. Jakarta: AIPI dan Gramedia Pustakan Utama.

www.covid.go.id

www.aladokter.com

www.kompas.com 